\title{
SISTEM INFORMASI PENILAIAN KINERJA UNIT PELAYANAN (STUDI KASUS : RUMAH SAKIT UMUM DAERAH POLEWALI)
}

\author{
Ade Irma ${ }^{1}$, Syarli² $^{2}$ Muhammad Sarjan ${ }^{3}$ \\ Program Studi Sistem Informasi ${ }^{1,3}$ \\ Program Studi Teknik Informartika ${ }^{2}$ \\ Universitas Al Asyariah Mandar \\ Jalan Budi Utomo No. 2 Madatte, Kab. Polewali Mandar, Prov. Sulawesi Barat \\ Email: irmaade@gmail.com
}

\begin{abstract}
ABSTRAK
Rumah sakit umum daerah polewali selama ini belum didukung program atau informasi yang terkomputerisasi dengan baik, khususnya pada pengolahan data kinerja unit pelayanan. Dengan kondisi ini menyebabkan pengolahan data yang tidak efisien. Hal ini tentu saja tidak sesuai dengan harapan karena mengingat bahwa teknologi saat ini telah berkembang sangat pesat yang pemanfaatannya dapat diaplikasikan dalam segala bidang. Penelitian ini bertujuan untuk merancang sistem informasi penilaian kinerja unit pelayanan rumah sakit umum daerah polewali berbasis web yang dapat mengolah data kinerja unit pelayanan lebih efektif. Sistem ini dirancang dengan menggunakan PHP dan database MySQL. Metode yang digunakan penulis berdasarkan pada Keputusan Menteri Pendayagunaan Aparatur Negara. Sistem ini dapat memberikan hasil akhir berupa diagram batang sehingga admin dengan mudah melihat perbandingan kinerja unit pelayanan yang satu dengan yang lainnya.
\end{abstract}

Kata Kunci: Sistem Informasi Manajemen, Penilaian Kinerja, RSUD

\begin{abstract}
Public hospitals polewali area has not been supported by the program or information is computerized well, especially on data processing service unit performance. With these conditions lead to inefficient data processing. This is of course not in accordance with expectations because given that the current technology has grown very rapidly that utilization can be applied in all fields. This study aims to design an information system performance appraisal service unit general hospital area polewali web-based that can process data service unit performance more effective. This system is designed using PHP and MySQL database. The method used by the author based on the Decree of the Minister of Administrative Reform. This system can provide the final result of a bar chart so that the admin easily see the comparison of service unit performance with each other.
\end{abstract}

Keywords: Management Information System, Performance Assessment, RSUD 


\section{PENDAHULUAN}

Pemerintah diwajibkan meningkatkan kualitas dan menjamin penyediaan pelayanan publik, salah satunya sebagaimana diamanatkan dalam Keputusan Menteri Pendayagunaan Aparatur Negara Nomor: KEP/25/M.PAN/2/2004 [1] .Rumah Sakit Umum Daerah (RSUD) Polewali merupakan salah satu instansi pemerintah yang bergerak dibidang pelayanan kesehatan. Pada rumah sakit umum daerah polewali tersebut telah melakukan survey secara periodik dan berkesinambungan untuk membandingkan kinerja pegawai pada masing-masing unit pelayanan. Jangka waktu survey yang dilakukan tiap tiga bulan antara periode satu dengan periode selanjutnya. pengolahan data survey dilakukan secara konvensional dan berulang ulang setiap periodenya, khususnya pada pengolahan data kinerja unit pelayanan, keadaan ini menciptakan kondisi yang tidak efesien, seperti pengumpulan data dan pengolahan data kuesioner yang membutuhkan banyak waktu. Kondisi ini dapat menciptakan hasil yang tidak efektif terlebih ketika akan melakukan perhitungan Indeks Kepuasan Masyarakat (IKM) sebagai indikator utama [8],[9].

Penilaian prestasi karyawan mutlak harus dilakukan untuk mengetahui prestasi yang hendak dicapai setiap karyawan dan setiap perusahaan memiliki cara yang berbeda dalam melakukan penilaian kinerja karyawan. Tentunya kegiatan penilaian atas prestasi kerja para karyawan harus dilakukan dengan metode yang baik dan tepat, sehingga tidak terjadi kesalahan dalam penilaian [6]. Penilaian dapat dilakukan dengan menggunakan kuesioner kemudian melakukan perangkingan berdasarkan hasil kuesioner [8]. Aplikasi kuesioner kinerja dapat dibangun menggunakan pemrograman PHP dan database MySQL sehingga dihasilkan sebuah sistemyang berbasis web. Sistem ini dapat memberikan hasil perhitungan yang cepat [2].

Rumah Sakit Umum Daerah (RSUD) Polewali yang secara rutin melakukan kegiatan ini belum didukung program atau sistem informasi yang terkomputerisasi dengan baik, sehingga dibutuhkan sebuah pendekatan teknologi yang dapat membantu mengotomatisasi pekerjaan yang secara periode dilakukan berulang kali. Sistem pengukuran kinerja yang baik dapat di terapkan berbasis web [2].

Dengan kata lain melalui perancangan sistem informasi dalam hal pengolahan data berbasis web pada RSUD Polewali dalam melakukan pengumpulan data dan pengolahan data serta melakukan perhitungan IKM dapat lebih cepat, tepat dan akurat. Penelitian akan mencoba mendesain sebuah sistem informasi yang akan memberikan solusi atas persoalan ini.

\section{TINJAUAN PUSTAKA}

Penilaian kinerja karyawan dapat dilakukan dengan berbagai metode atau pendekan salah satunya adalah dengan menggunakan Model Fuzzy Multi Attribute Decision Making Metode Simple Additive Weighted [6], [8]. Fuzzy Multi Attribute Decision Making Metode Simple Additive Weighted (MADM) dapat melakukan penilaian dan perangkingan prestasi kerja karyawan. Sehingga lebih mempermudah dalam proses penentuan kinerja [8].

\section{Kinerja RSUD Polewali}

Rumah Sakit Umum Daerah (RSUD) Polewali merupakan pelayanan kesehatan yang status kelas C berdasarkan SK Menteri Kesehatan RI No. 543 /Menkes/Sk/VI/1996 sejalan dengan meningkatnya permintaan pelayanan kesehatan dan mempunyai kemampuan pelayanan medis spesialistik dasar dan pelayanan spesialistik luas.

Kinerja pegawai RSUD ditentukan berdasarkan Indeks Kepuasan Masyarakat (IKM) yaitu data dan informasi tentang tingkat kepuasan masyarakat yang diperoleh adalah hasil survey dan pengukuran secara kuantitatif dan kualitatif atas pendapat masyarakat dalam memperoleh pelayanan dari aparatur penyelenggara pelayanan publik dengan membandingkan antara harapandan kebutuhannya. Survey dilakukan secara komprehensif, Unsur Survei Kepuasaan Masyarakat adalah faktor dan aspek yang dijadikan pengukuran kepuasan masyarakat terhadap penyelenggaraan pelayanan publik [4].

Berdasarkan undang-undang keputusan menteri pendayagunaan aparatur negara NOMOR: KEP/25/M.PAN/2/2004 mengenai pedoman umum penyusunan IKM [1] serta prinsip pelayanan sebagaimana telah ditetapkan dalam Keputusan Menteri PAN Nomor: 63/KEP/M.PAN/7/2003 maka terdapat 14 unsur yang relevan, sebagai unsur minimal yang harus ada untuk dasar pengukuran indeks kepuasan masyarakat adalah sebagai berikut [2]:

1. Prosedur pelayanan, yaitu kemudahan tahapan pelayanan yang diberikan kepada masyarakat dilihat dari sisi kesederhanaan alur pelayanan;

2. Persyaratan Pelayanan, yaitu persyaratan teknis dan administratif yang diperlukan untuk mendapatkan pelayanan sesuai dengan jenis pelayanannya;

3. Kejelasan petugas pelayanan, yaitu keberadaan dan kepastian petugas yang memberikan pelayanan (nama, jabatan serta kewenangan dan tanggung jawabnya);

4. Kedisiplinan petugas pelayanan, yaitu kesungguhan petugas dalam memberikan pelayanan terutama terhadap konsistensi waktu kerja sesuai ketentuan yang berlaku;

5. Tanggung jawab petugas pelayanan, yaitu kejelasan wewenang dan tanggung jawab 
petugas dalam penyelenggaraan dan penyelesaian pelayanan;

6. Kemampuan petugas pelayanan, yaitu tingkat keahlian dan ketrampilan yang dimiliki petugas dalam memberikan/ menyelesaikan pelayanan kepada masyarakat;

7. Kecepatan pelayanan, yaitu target waktu pelayanan dapat diselesaikan dalam waktu yang telah ditentukan oleh unit penyelenggara pelayanan;

8. Keadilan mendapatkan pelayanan, yaitu pelaksanaan pelayanan dengan tidak membedakan golongan/status masyarakat yang dilayani;

9. Kesopanan dan keramahan petugas, yaitu sikap dan perilaku petugas dalam memberikan pelayanan kepada masyarakat secara sopan dan ramah serta saling menghargai dan menghormati;

10. Kewajaran biaya pelayanan, yaitu keterjangkauan masyarakat terhadap besamya biaya yang ditetapkan oleh unit pelayanan;

11. Kepastian biaya pelayanan, yaitu kesesuaian antara biaya yang dibayarkan dengan biaya yang telah ditetapkan;

12. Kepastian jadwal pelayanan, yaitu pelaksanaan waktu pelayanan, sesuai dengan ketentuan yang telah ditetapkan;

13. Kenyamanan lingkungan, yaitu kondisi sarana dan prasarana pelayanan yang bersih, rapi, dan teratur sehingga dapat memberikan rasa nyaman kepada penerima pelayanan;

14. Keamanan Pelayanan, yaitu terjaminnya tingkat keamanan lingkungan unit penyelenggara pelayanan ataupun sarana yang digunakan, sehingga masyarakat merasa tenang untuk mendapatkan pelayanan terhadap resiko-resiko yang diakibatkan dari pelaksanaan pelayanan;

\section{Perhitungan Nilai Indeks}

Nilai indeks kepuasan masyarakat dihitung dengan menggunakan "nilai rata-rata tertimbang" masing-masing unsur pelayanan. Dalam penghitungan indeks kepuasan masyarakat terhadap 14 unsur pelayanan yang dikaji (Mote, F., 2008), setiap unsur pelayanan memiliki penimbang yang sama dengan rumus sebagai berikut:

$$
\begin{aligned}
& \text { Bobot nilai rata }- \text { rata tertimbang } \\
& \qquad=\frac{\text { jumlah bobot }}{\text { jumlah unsur }}+\frac{1}{14}=0.071
\end{aligned}
$$

Untuk memperoleh nilai indeks kepuasan masyarakat unit pelayanan digunakan pendekatan nilai rata-rata tertimbang dengan rumus sebagai berikut:

$$
\begin{array}{r}
\mathrm{IKM}=\frac{\text { total dari nilai persepsi perunsur }}{\text { total unsur yang terisi }} \\
* \text { nilai penimbang }
\end{array}
$$

Untuk nilai persepsi, interval IKM, interval konversi ikm, mutu pelayanan dankinerja unit pelayanan ditunjukkan pada tabel 2.1.

Tabel 2.1 tabel nilai persepsi, interval ikm, interval konversi ikm, mutu pelayanan dankinerja unit pelayanan (Mote, F., 2008))

\begin{tabular}{|c|c|c|c|c|}
\hline $\begin{array}{c}\text { NILAI } \\
\text { PERSE } \\
\text { PSI }\end{array}$ & $\begin{array}{c}\text { NILAI } \\
\text { INTERVAL } \\
\text { IKM }\end{array}$ & $\begin{array}{c}\text { NILAI } \\
\text { INTERVAL } \\
\text { KONVERSI } \\
\text { IKM }\end{array}$ & $\begin{array}{c}\text { MUTU } \\
\text { PELAY } \\
\text { ANAN }\end{array}$ & $\begin{array}{c}\text { KINERJA UNIT } \\
\text { PELAYANAN }\end{array}$ \\
\hline 1 & $1.00-1.75$ & $25-43,37$ & D & Tidak baik \\
\hline 2 & $1.76-2.50$ & $43.76-62.50$ & $\mathrm{C}$ & Kurang baik \\
\hline 3 & $2.51-3.25$ & $62.51-81.25$ & $\mathrm{~B}$ & Baik \\
\hline 4 & $3.26-4.00$ & $81.26-100$ & $\mathrm{~A}$ & Sangat baik \\
\hline
\end{tabular}

Tabel diatas merupakan tabel rentang nilai yang digunakan sebagai dasar tingkat kepuasan masyarakat terhadap pelayanan yang ada di RSUD Polewali.

Berdasarkan hasil penghitungan indeks kepuasan masyarakat, jumlah nilai dari setiap unit pelayanan diperoleh dari jumlah nilai rata-rata setiap unsur pelayanan. Sedangkan nilai indeks komposit (gabungan) untuk setiap unit pelayanan, merupakan jumlah nilai rata-rata dari setiap unsur pelayanan dikalikan dengan penimbang yang sama, yaitu 0,071 .

\section{METODE PENELITIAN}

Penelitian akan dilakukan pada RSUD Polewali Mandar, digunakan kuisioner untuk mengumpulkan pendapat responden tentang pelayanan publik RSUD Polewali. Kuisioner yang digunakan bersifat tertutup karena sudah disediakan pilihan jawaban yang akan dipilih oleh responden. Sebanyak sepuluh kuisioner atau Setara dengan sepuluh responden dijadikan sampel dan diminta untuk menilai kinerja setiap unit pelayanan, ini dimaksudkan untuk melihat dan memastikan sistem yang dibangun dapat melakukan perhitungan nilai indeks dengan baik maka dilakukan pengambilan data sampel masing-masing sepuluh responden setiap unit yang dipilih secara acak untuk melakukan pengisia terhadap kuesioner yang telah dibuat berbasis web applikasi. Pertanyaa kuesioner disusun berdasarkan 14 unsur minimal yang ada pada pengukuran indeks kepuasan masyarakat. Adapun kerangka sistem web aplikasi dapat dilihat pada gambar 3.1. 


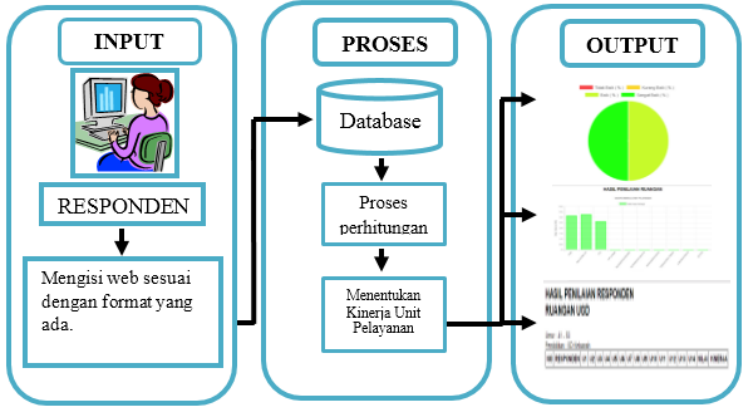

Gambar 3.1. Kerangka Sistem

Kerangka sistem menunjukkan bahwa responden mengisi data diri pada website sesuai dengan format yang ada, setelah itu data tersebut tersimpan dalam database kemudian di proses menggunakan rumus yang telah ditetapkan oleh keputusan menteri pendayagunaan aparatur negara. Outputnya berupa diagram batang agar kita dapat melihat dengan jelas kualitas pelayanan yang diberikan pada tiap unit pelayanan. Flowchart sistem yang diusulkan dapat dilihat pada gambar 3.2.

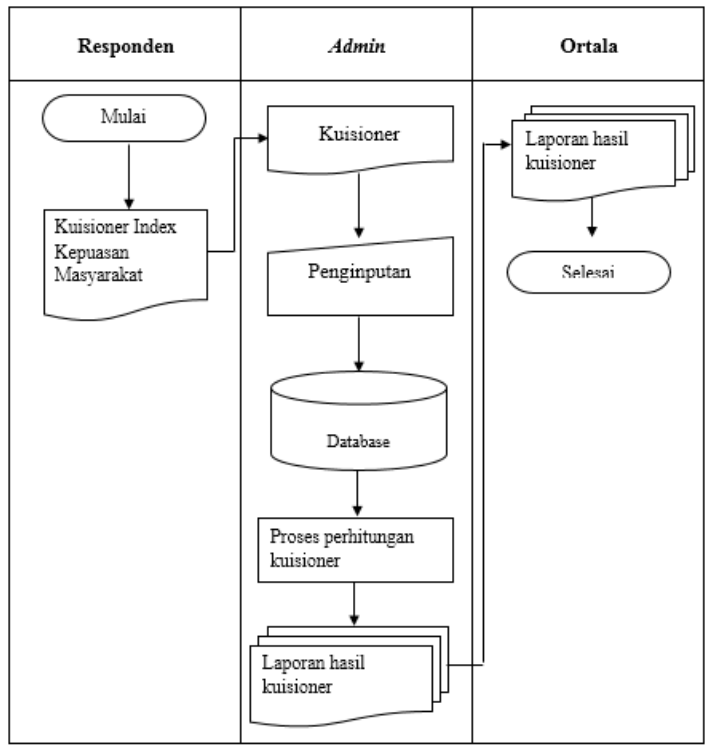

Gambar 3.2. Flowchart sistem yang diusulkan

Responden mengisi kuisioner yang tertera pada halaman utama website mengisi data diri dan menjawab pertanyaan kuisioner yang ada. Admin menginput hasil kuisioner tersebut yang akan tersimpan dalam database lalu dihitung berdasarkan rumus yang telah ditetapkan menggunakan aplikasi berbasis website dan hasil akhir kuisioner tersebut di tampilkan dalam bentuk diagram batang dan diagram lingkaran. Diagram konteks ditunjukkan pada gambar 3.3.

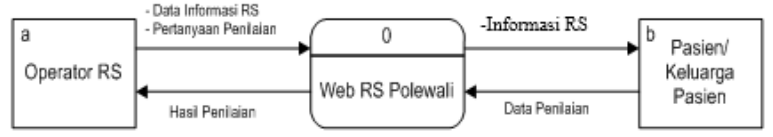

Gambar 3.3. Diagram Konteks

Operator rumah sakit umum daerah polewali menginput data informasi rumah sakit, berupa profil, galeri, dan struktur organisasi kemudian menginput semua pertanyaan-pertanyaan yang berkaitan dengan kinerja unit pelayanan. Kemudian Pasien atau keluarga pasien sebagai responden akan mengisi pertanyaan-pertanyaan yang telah dibuat. Setiap jawaban atau isian kuesioner secara langsung akan masuk ke database MySQL dan diproses oleh sistem tanpa harus menunggu waktu yang lama. Berikut kami sajikan potongan kode pemrogaman PHP yang akan melakukan perhitungan. Gambar 3.4.

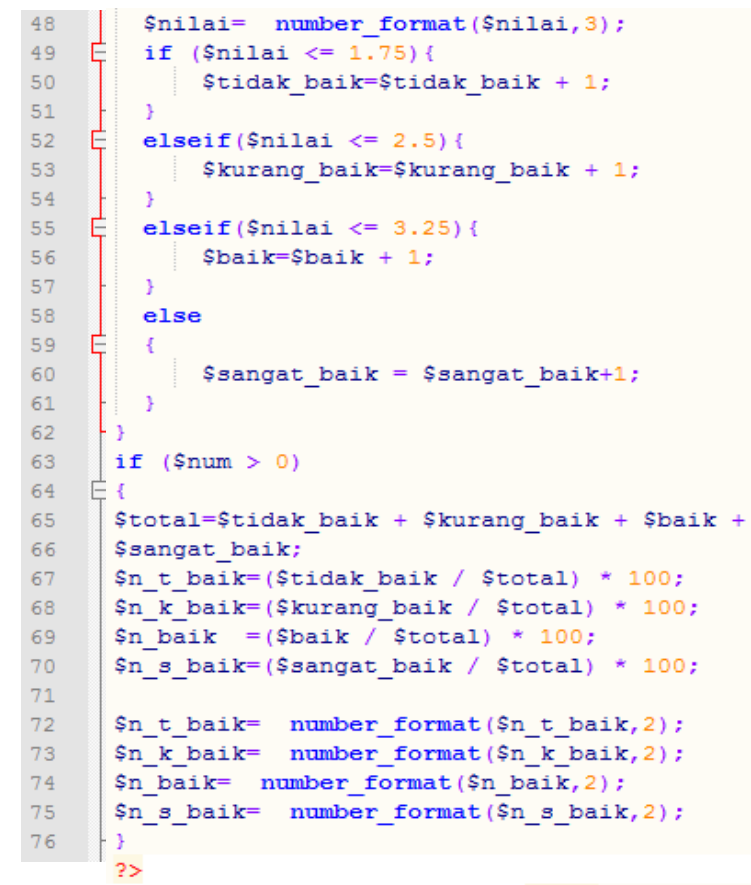

Gambar 3.4. Kode Pemrograman PHP untuk proses perhitungan

Kode pemrograman PHP gambar 3.4. dapat kita lihat pada baris 48-60 merupkakan aturan yang dibuat dan telah disesuaikan dengan tabel 2.1. Serta baris 65-75 adalah rumus perhitungan bobot nilai rata-rata dan perhitungan IKM. Setelah dilakukan proses perhitungan oleh sistem maka hasil penilaian kinerja unit pelayanan rumah sakit umum daerah polewali dapat dilihat oleh operator secara real time.

\section{HASIL PENELITIAN}

Perancangan sistem informasi penilaian kinerja unit pelayanan memiliki 2 level akses yaitu akses Administrator yaitu penanggung jawab sistem penilaian kinerja unit pelayanan dan pengunjung 
sebagai responden yang akan melakukan pengisian kuesioer secara online. Halaman utaman sistem ditunjukkan pada gambar 4.1.

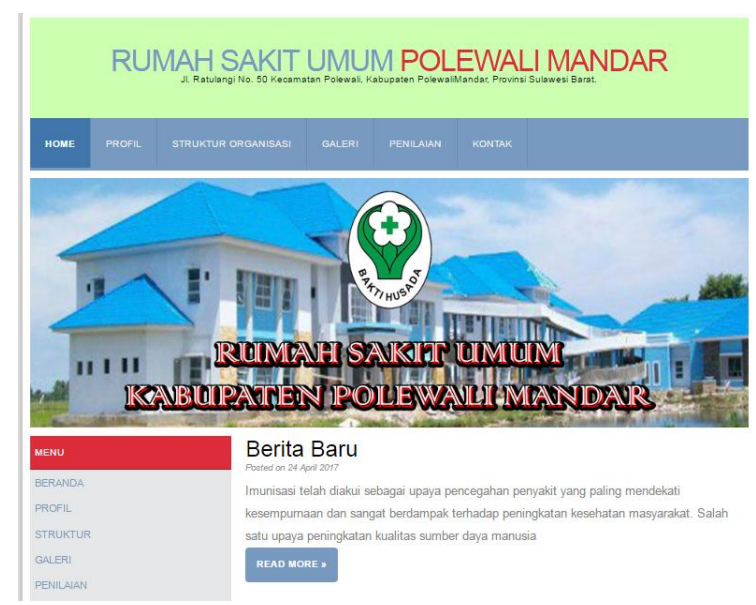

Gambar 4.1. Halaman Utama Sistem

Gambar 4.1. merupakan tampilan awal saat program pelayanan rumah sakit ini mulai diakses. Untuk dapat melakukan pengisian kuesioner atau penilaian terhadap kinerja pegawai maka setiap responden diharuskan mengisi biodata terlebih dahulu ini ditunjukkan pada gambar 4.2.

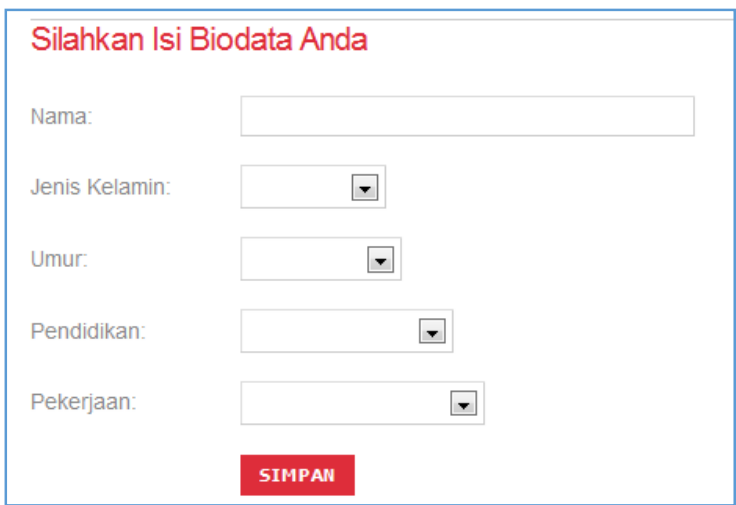

Gambar 4.2. Biodata Responden

Gambar 4.2. menunjukkan form isi biodata untuk responden atau pendamping pasien. Form ini adalah tahap awal sebelum mengisi kuesioner penilaian. Data responden atau penilai akan dikelola admin pada halaman administrator. Data Penilai dapat dilihat pada gambar 4.3.

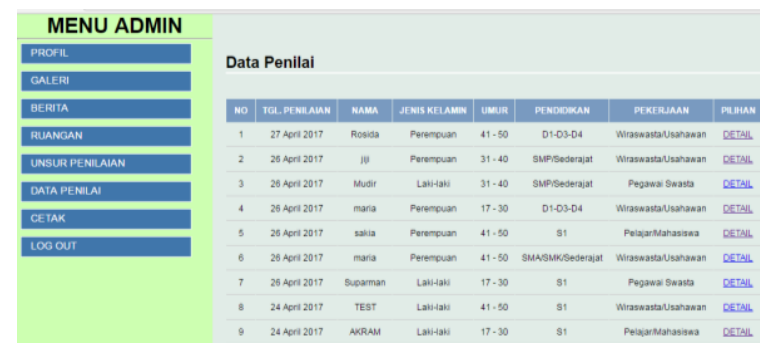

Gambar 4.3. Data Responden atau Penilai
Data yang ditunjukkan pada gambar 4.3. merupakan data-data responden yang telah melakukan pengisian pada menu utama penilaian. Adapun unit pelayanan yang akan dinilai akan dikelola oleh administor pada halaman Data Ruangan Rumah Sakit seperti yang ditunjukkan pada gambar 4.4.

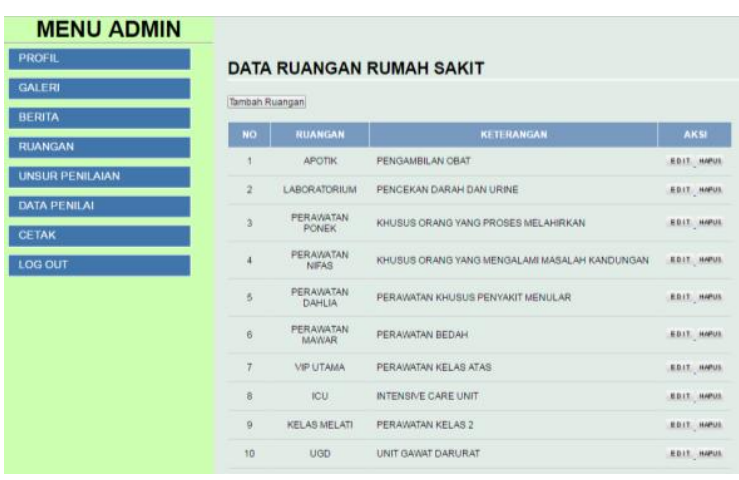

Gambar 4.4. Data Ruangan yang dinilai

Admin dapat memasukkan nama-nama ruangan yang ada pada rumah sakit umum daerah polewali. Kemudian menentukan ruangan mana yang akan dilakukan penilaian terhadapa kinerja layanan. Adapun unsur penilaian ditunjukkan pada gambar 4.5 .

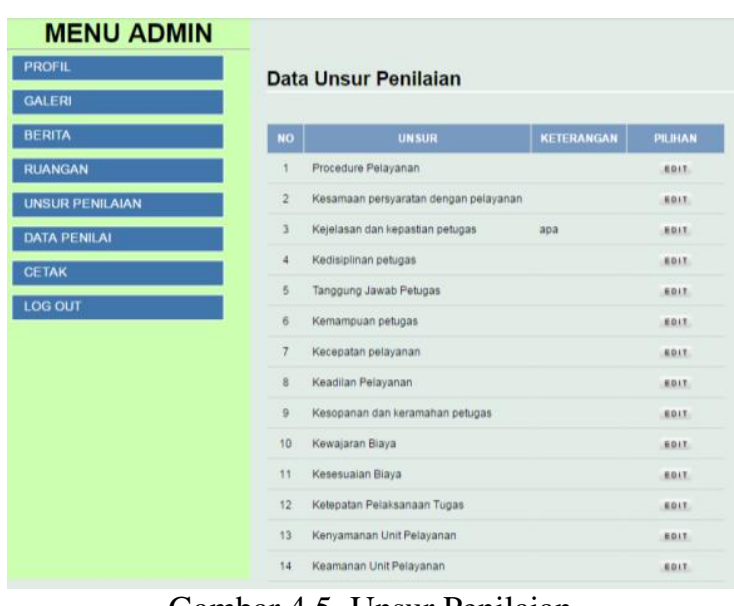

Gambar 4.5. Unsur Penilaian

Gambar 4.5. merupakan tampilan kuisioner yang menjadi unsur-unsur pertanyaan mengenai pelayanan yang ada di rumah sakit umum daerah polewali. Kuesioner ini juga dikelola oleh administrator.

Setelah pengisian biodata oleh responden selesai, selanjutnya memilih ruangan yang akan dinilai setelah pengisian kuesioner penilaian juga telah selesai maka data yang masuk kedalam databse akan diproses dan dilakukan perhitungan sebagaimana aturan pemrograman yang telah dibuat pada gambar 3.4. Hasil dapat langsung dicetak. 


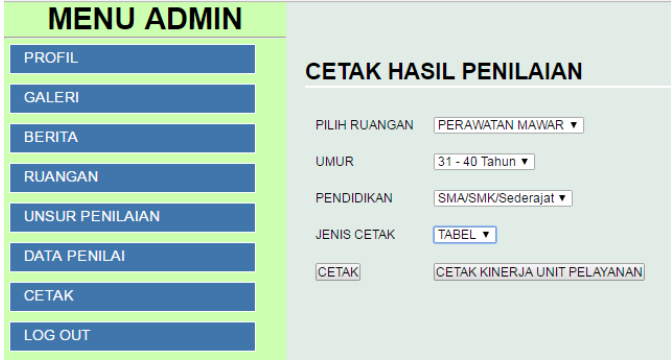

Gambar 4.6. Halaman Cetak Penilaian

Admin dapat memilih ruangan yang ingin dilihat kualitas pelayanannya berdasarkan klasifikasi umur dan pendidikan, hasilnya dapat dicetak berupa tabel maupun berupa diagram lingkaran. Apabila Admin ingin melihat perbandingan kinerja antar unit pelayanan yang satu dengan yang lainnya dapat dilihat dengan mengklik cetak kinerja unit pelayanan. Gambar 4.6. Hasil penilaian kinerja berdasarkan ruangan.

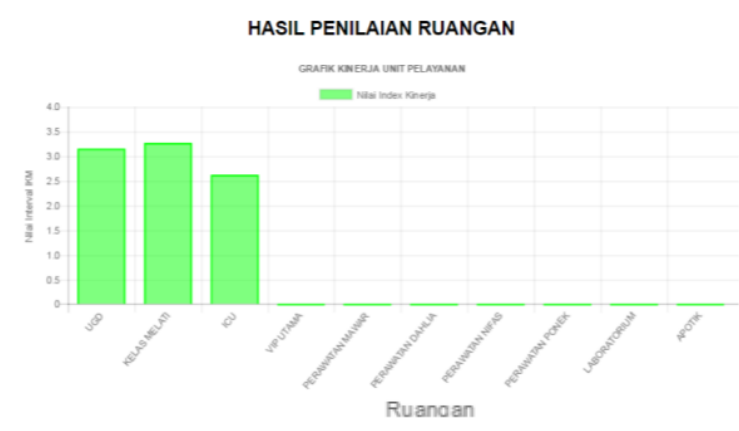

\begin{tabular}{|c|c|}
\hline \multicolumn{2}{|c|}{ TABEL RENTANG NILAI } \\
\hline NILAI INTERVAL IKM & KINERJA UNIT PELAYANAN \\
\hline $1,00-1,75$ & Tidak Baik \\
\hline $1,78-2,50$ & Kurang Baik \\
\hline $2,51-3,25$ & Baik \\
\hline $3.26-4,00$ & Sangat Baik \\
\hline
\end{tabular}

Gambar 4.6. Hasil Penilaian Kinerja

Gambar 4.6. merupakan tampilan diagram batang penilaian kinerja unit pelayanan sehingga kita dapat melihat dengan mudah perbandingan kinerja antara unit pelayanan satu dengan yang lainnya.

Penelitian juga ini menyajikan laporan penialain pada salah satu ruangan yang ada di RSUD Polewali, hasil laporan dapat dilihat pada gambar 4.7. Penilaian dibuat berdasarkan interval nilai pada tabel 2.1. tentang nilai persepsi dan gambar 4.6. yang menunjukkan tabel rentang nilai.
HASIL PENILAIAN RUANGAN KELAS MELATI

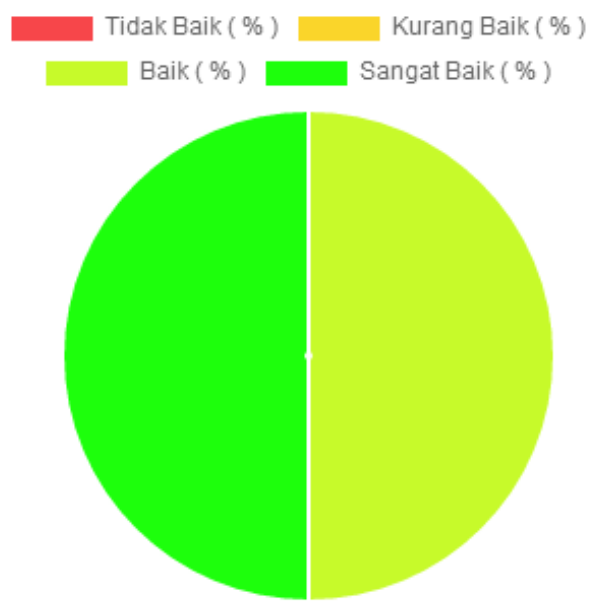

\begin{tabular}{|l|l|}
\hline JUMLAH RESPONDEN & $\mathbf{2}$ Orang \\
\hline TIDAK BAIK & 0 Orang \\
\hline KURANG BAIK & 0 Orang \\
\hline BAIK & 1 Orang \\
\hline SANGAT BAIK & 1 Orang \\
\hline
\end{tabular}

Gambar 4.7. Laporan Hasil Penilaian Ruangan

Grafik Pie akan membentuk warna berdasarkan Tabel nilai rentang kemudian memberikan nilai presentasi pada setian jawaban responden.

\section{KESIMPULAN}

Penelitian ini menghasilkan suatu sistem informasi penilaian kinerja unit pelayanan rumah sakit umum daerah polewali berbasis web yang dapat mengolah data kinerja unit pelayanan lebih efektif. Sistem ini dirancang dengan menggunakan PHP dan database MySQL. Metode yang digunakan penulis berdasarkan pada Keputusan Menteri Pendayagunaan Aparatur Negara. Sistem ini memberikan hasil akhir berupa diagram batang sehingga Admin dengan mudah melihat perbandingan kinerja unit pelayanan yang satu dengan yang lainnya.Penelitian ini dapat dikembangkan oleh peneliti selanjutnya dengan menambahkan output dalam bentuk infografis , dimana terdapat beberapa perincian tentang Informasi ruangan rawat inap yang kosong, jumlah unit pelayanan berserta fasilitas-fasilitas dari setiap ruangannya, serta menambahkan petunjuk jalan untuk menuju keruangan-ruangan tertentu serta membuat aplikasi pendaftaran online untuk loket.

\section{Daftar Pustaka}

[1] Kepmenpan RI No. KEP/25/M.PAN/2/2004 tentang Pedoman Umum Penyusunan IKM Unit Pelayanan Instansi Pemerintah. 
[2] Loamena., D.Z.,Syamsudin, D., Syahrizal, 2013, Penerapan Web Untuk Aplikasi Kuisioner Kinerja Pada Universitas Islam Attahiriyah.

[3] Mote F., 2008 Nalisis Indeks Kepuasan Masyarakat (IKM) Terhadap Pelayanan Publik Di Puskesmas Ngesrep Semarang, Tesis, Program Pascasarjana Universitas Diponegoro Program Studi : Magister Ilmu Administrasi Konsentrasi : Magister Administrasi Publik.

[4] Peraturan menteri pendayagunaan aparatur negara dan Reformasi birokrasi Republik Indonesia Nomor 16 tahun 2014 Tentang Pedoman survei kepuasan masyarakat terhadap penyelenggaraan Pelayanan publik

[5] Republik Indonesia, 2004, Pedoman Umum Penyusunan Indeks Kepuasan Masyarakat Unit Pelayanan Instansi Pemerintah. Jakarta : Kementrian Pendayagunaan Aparatur Negara Republik Indonesia.
[6] Maulana. R.M., 2012, Penilaian Kinerja Karyawan di Ifun Jaya Textile dengan Metode Fuzzy Addictive Weighted. Pekalongan, STIMIK WIDYA PRATAMA.

[7] Mentri PAN-RI, 2003, Pedoman Umum Penyelenggaraan Pelayanan Publik Menteri Pendayagunaan Aparatur Negara

[8] Savitri Irma Ayu, dkk, 2012, Penilaian Kinerja Karyawan dengan Model Fuzzy Multy Attribute Decission Making Metode Simple Addictive Weighted. Malang, UNIVERSITAS BRAWIJAYA.

[9] Sulistiyani, Hasiolan L.B, Warso, M.M., 2016, Analisis Pengaruh Indeks Kepuasan Masyarakat Terhadap Pelayanan Publik di Kelurahan Pudakpayung Kecamatan Banyumanik Kota Semarang “. Journal of management, Volume 2 No. 2 maret 2016 